\title{
Macroeconomic Structural Change in Indonesia: in The Period of 1990 to 2011
}

\author{
Muhammad Yunanto and Henny Medyawati
}

\begin{abstract}
The purpose of this study is to analyze the structural changes in the Indonesian economy in relation to the implementation of fiscal and monetary policy on output variables (GDP). Model in this study is the simultaneous equations model which consists of 11 equations. Analysis was done through short-term estimation with Error Correction Model (ECM) and long-term estimates by Two Stage Least Square (TSLS). The estimation results indicate that the variable interest rates have a positive impact on the strengthening of the exchange rate. Fiscal policy and monetary policy is an integral part of macroeconomic policy has a target to be achieved in both the short and long term. Fiscal policy which may result in increase in the rate of inflation, otherwise the economy with high inflation rates also negatively affect the increase in Gross Domestic Product
\end{abstract}

Index Terms-Mundell-Flemming model, fiscal policy, monetary policy.

\section{INTRODUCTION}

Significant effect of fiscal policy on the economy put forward by Keynes. Before Keynes, the government's financial operations have not seen a significant influence on the level of employment and aggregate demand. The role of government at that time was limited to relocate the financial resources from the private sector to the government. This view was put forward by including Say's Law that in conditions of full employment, any additional government spending will cause a decrease in private spending (crowd-out) in the same amount and the expenditure will not change the aggregate income.

Some research results to the case in Indonesia shows that the rapid change in the Indonesian financial sector has led to the creation of money by the activities of the central bank. This in turn led to the behavior of the money multiplier (money multiplier) tends to be unstable. Furthermore, this trend is not only happening on the behavior of the money multiplier, but also the income velocity and the money demand function [1].

On the condition of under-capacity economy, expansionary fiscal and monetary policy affects real output effectively. Amid weak global demand due to the global financial crisis, fiscal stimulus can reduce domestic economic problems. Furthermore, the strong aggregate demand can give multiple effects and increase aggregate supply in the real sector. Expansionary fiscal policy, through fiscal stimulus to boost aggregate demand through domestic

Manuscript received April 20, 2013; revised June 19, 2013. This paper is a part of M.Yunanto dissertation.

M. Yunanto and H. Medyawati are with lecturer in Gunadarma University Faculty of Economics, Indonesia (e-mail: myunanto@ staff.gunadarma.ac.id, henmedya@staff.gunadarma.ac.id). consumption and investment, assuming constant prices, short term real output will increase [2].

Compared with fiscal stimulus that can immediately increase economic activity, monetary policy needs more time to show the impact on the economy. This is because the primary objective of monetary policy is to maintain a stable output gap and inflation. In developed countries, like the United States and some major European countries, there is substantial evidence of the effectiveness of monetary policy innovations on the parameters of the real economy, [3]-[6].

Based on empirical fact, the main problem in this study related to the impact of fiscal and monetary policy is how structural changes affect the implementation of the Indonesian economy of fiscal and monetary policy on output variables (GDP)? This study is a continuation of previous research is the study of the literature to determine the proper estimation models for Indonesia [7]. The purpose of the research is to analyze the structural macroeconomic, using simultaneous equation model to estimate in terms of fiscal and monetary policy strategy with the ultimate goal the output (GDP).

\section{THEORETICAL FRAMEWORK}

\section{A. Mundell-Flemming Theory}

Indonesia can be characterized as a country mentioned small open economy (small-open economic) that macroeconomic fluctuations in response to the global economy. Small open economy is an economy with capital mobility assumption (of capital inflows / out) is perfect. Another characteristic is the small open economies [8]: (1) the economy with a very high level of dependence on the global economy, (2) a relatively stable economy, with high levels of vulnerability to shocks from abroad, and (3) the high degree of dependence on changes in international prices. Mundell-Fleming theory or model of two states (two-country model) is an analytical framework that can be used to explain the international transmission due to the influence of the global economy in a small open economy. This theory explains that the expansion of monetary policy will result in an increase in a country's output and produce a negative output response in other countries. Transmission mechanism of the model can be seen via trade, where a country will lower interest rates, the exchange rate depreciates and create competitive rivalry. That way a country will have a surplus in the trade balances due to the increase of exported products (and declining imports products from other countries). Shocks due to change in crude oil prices as a representation of the level of world inflation and world interest rates, show significantly implications on domestic variables. It shows Indonesia as a small open economy highly vulnerable to 
shocks variable world [8]. Reference [2] states that the fiscal and monetary policy affects effectively to the real output. Expansionary fiscal policy, through fiscal stimulus, can increase aggregate demand through domestic consumption and investment. Under conditions of price stickiness, the short-term of real output will increase. Amid weak global demand due to the global financial crisis, fiscal stimulus can catalyze domestic economy. Furthermore, the strong aggregate demand can give the effect of folds and increase aggregate supply in the real sector, in accordance with the economy under capacity (under capacity economy), which in turn can increase output in the short run.

\section{B. Related Research}

Reference [9] using a variation of Mundell-Fleming model to analyze whether monetary policy can stabilize macroeconomic fluctuations Indonesia, as a country open economy with a floating exchange rate system by using the methodology Structural Vector Auto Regressive (SVAR). The empirical results show that the transmission mechanism of monetary policy can be evaluated from the impulse response analysis. This analysis suggests that the shock of the impact of monetary policy on output through a short-term impact on domestic interest rate on the real exchange rate. However, this study suggests that in order to stabilize macroeconomic fluctuations Indonesia, both fiscal and monetary policy should work together.

Research conducted by [10] shows that fiscal policy worldwide expansion combined with accommodative monetary policy can have a significant multiplier effect on the world economy. Reference [11] and [12] finds that the fiscal stimulus of 1 percent of GDP result in increased GDP by almost 1 percentage point and as much as 2 to 3 percent of GDP at the peak effect occurs, a few years later.

While, [13] found a smaller multiplier for European countries. Reference [10] found both government spending and transfer payments targeted will have a considerable multiplier effect on the economy. In an ideal scenario where fiscal stimulus, both globally and supported by monetary accommodation and the financial sector is under pressure is being supported by the government. Meanwhile, cross-country study conducted by [14] found that a small fiscal multiplier for the economy and in some cases were multiplier with a negative sign. Studies conducted by [15], and surveyed by [16] also found that fiscal expansion has a negative multiplier effect on the economy.

Reference [17] examined the interaction of fiscal and monetary policy in Indonesia before and after the 1997 economic crisis. The research carried out estimation of quasi fiscal activities of the central bank (QFA) and also assessing fiscal versus the monetary dominance aspect. The findings in this study indicate that the policy implication of monetary policy in Indonesia requires the support and commitment of fiscal discipline to maintain its sustainability. Reference [18] show that a little or a lot, the budget deficit policy affects interest rates, exchange rates and the price level (inflation). In addition, there was an interrelationship between the budget deficit and the policy of monetary variables. Fiscal policy affects monetary instrument, as well as fiscal policy affect monetary policy. Reference [19] states that the optimal monetary policy response will be affected by some shocks scenario on fiscal policy, and the impact of monetary and fiscal policy interactions on social welfare will be positive if the fiscal policy is exogenous.

\section{Methodology}

This study was conducted to analyze the impact of synergy optimization fiscal and monetary policy to GDP of Indonesia. Data used in this study is time series data in the period 1990:1 to 2011:4. Sources of data are collection from Financial Statistics (IFS) published by Bank Indonesia, Central Bureau of Statistics (BPS) while other data sourced from the Organization for Economic Co-operation and Development (OECD).

Aggregate supply model used in this study was adopted from the model calculations performed by [20] which is the development of a model of open economy macro by [21]. In his model, the inflation use as measured by the survey of living costs (cost of living index) as a factor affecting aggregate supply with a positive relationship. The higher inflation (price level) then there is an incentive for producers to increase production so as to increase aggregate supply. Whereas the aggregate supply relationship with the investment is positive that any increase investment, which means there will be an increase in production capacity due to increased capital stock and can further increase the aggregate supply. Simultaneous equation model consists of three blocks, namely block of goods market, money market blocks and blocks of aggregate supply

Block of Goods Market:

Private consumption equation

$K O N S=f\left(Y_{D}\right.$, BIRATE $)$

$$
\begin{gathered}
C_{t}=\alpha_{0}+\alpha_{1}(Y-T x+T r)_{t}+\alpha_{2} i_{t}+\varepsilon_{1 t} \\
\alpha_{2}<0 ; \alpha_{1}>0
\end{gathered}
$$

Investment Equation

$$
I N V=f(K B L N, B I R A T E)
$$

$$
\beta_{2}<0 ; \beta_{1}>0{ }^{I}=\beta_{0}+\beta_{1} F_{t}+\beta_{2} i_{t}+\varepsilon_{2 t}
$$

Government Expenditure Equation

$$
\mathrm{KONP}_{t}=f(P P J K, P D B E)
$$

$$
\gamma_{0}, \gamma_{1}>0
$$

$$
G_{t}^{*}=\gamma_{0}+\gamma_{1} T x_{t}+\gamma_{2} Y_{t}+\varepsilon_{3 t}
$$

Export Equation

$$
\begin{gathered}
E K S P=f((\text { HREKS }), I M P D N) \\
X_{t}=\delta_{0}+\delta_{1}\left(r . P_{x}^{*} / P\right)_{t}+\delta_{2} M_{-} W_{t}+\varepsilon_{4 t} \\
\delta_{1}, \delta_{2}>0
\end{gathered}
$$

Import Equation

$$
\begin{aligned}
& I M P R=f(H R I M P), E K S P, Y D O M) \\
& M_{t}=\zeta_{0}+\zeta_{1}\left(r . P_{m}^{*} / P\right)_{t}+\zeta_{2} X+\zeta_{3}(C+I+G)_{t}+\varepsilon_{5 t} \\
& \zeta_{1}<0 ; \zeta_{2}, \zeta_{3}>0
\end{aligned}
$$

Money Supply Equation

$$
\begin{aligned}
& M_{D}=M_{S} \\
& M_{S} / I H K=M / I H K \\
& M_{D}=M / I H K \\
& M 2_{t}=f(M 1, P D B E, B I R A T E) \\
& \begin{array}{l}
M 2_{t}=\eta_{0}+\eta_{1} M 1+\eta_{2} Y_{t}+\eta_{3} i_{t}+\varepsilon_{6 \mathrm{t}} \\
\eta_{3}<0 ; \eta_{1}, \eta_{2}>0
\end{array}
\end{aligned}
$$

of the Balance of Payment:

Exchange Rate Equation

$$
\begin{gathered}
\text { KURS }=f(\text { IREL, BIRATE, KBLN }) \\
\quad r_{t}=\theta_{0}+\theta_{1}\left(P^{*} / P\right)_{t}+\theta_{2} i_{t}+\theta_{3} F_{t}+\varepsilon_{7 t} \\
\theta_{2}, \theta_{3}<0 ; \theta_{1}>0
\end{gathered}
$$


Price (inflation) and Purchasing Power Parity Equation $I H K=f((P P P), M 2, H M M D)$

$$
\begin{aligned}
& P_{t}=\kappa_{0}+\kappa_{l}\left(r \cdot P^{*}\right)_{t}+\kappa_{2} M 2_{t}+\kappa_{3} O i l_{-} W_{t}+\varepsilon_{8 t} \\
& \kappa_{1} \kappa_{2} \kappa_{3}>0
\end{aligned}
$$

Net Foreign Account Equation

$$
\begin{aligned}
& K B L N=f(R I N T R, K U R S) \\
& \qquad F_{t}=\lambda_{0}+\lambda_{1}\left(i-i^{*}\right)_{t}+\lambda_{2} r_{t} \varepsilon_{9 t} \\
& \lambda_{1}<0 \lambda_{2}>0 ;
\end{aligned}
$$

Block of Aggregate Supply:

National Production Equation

$P D B E=f(I N V, L K)$

$$
\begin{aligned}
Y_{t}=\mu_{0}+\mu_{1} I_{t}+\mu_{2} L_{t}+\varepsilon_{10 t} \\
\mu_{1}, \mu_{2, \mu_{3}>0}
\end{aligned}
$$

Employment Equation

$$
\begin{gathered}
L K=f(P D B E, I H K) \\
v_{1}, v_{2}>0
\end{gathered}
$$

\section{Notes:}

BIRATE $(i)$

$\operatorname{EKSP}(X)$

HREKS $\left(r . P_{x}^{*} / P\right)$

$\operatorname{HRIMP}\left(r . P_{m}^{*} / P\right)$

IHK $(P)$

$\operatorname{IHKD}\left(P^{*}\right)$

IMPR $(M)$

$\operatorname{IMPDN}\left(M_{-} W\right)$

$\operatorname{INV}(I)$

IREL $\left(P / P^{*}\right)$

$\operatorname{KBLN}(F)$

$\operatorname{KONP}\left(G^{*}\right)$

KONS $(C)$

$\operatorname{KURS}(r)$

LK $(L)$

M1

$\mathrm{M} 2=\mathrm{M}_{\mathrm{S}}$

$\operatorname{PDBE}(Y)$

$\operatorname{PPJK}(T x)$

$\operatorname{PPP}\left(r . P^{*}\right)$

RINTR $\left(i-i^{*}\right)$

SUBS $(T r)$

$\mathrm{Y}_{\mathrm{D}}(\mathrm{Y}-\mathrm{Tx}+\mathrm{Tr})$

$\mathrm{Y}_{\mathrm{DOM}}(\mathrm{C}+\mathrm{I}+\mathrm{G})$
HMMD $($ Oil $W)$

\author{
$=$ Bank of Indonesia Interest Rates \\ $=$ Export \\ $=$ International Crude Prices \\ $=$ The Relative Price of The Export Commodity \\ $=$ The Relative Price of the Import Commodity \\ $=$ Domestic Price Index \\ $=$ World Price Index \\ $=$ Import \\ $=$ World Import Demand \\ $=$ Gross Investment \\ $=$ Comparison between Domestic Price Index and \\ World Price Index \\ $=$ Net Foreign Asset \\ $=$ Government Consumption \\ $=$ Private Consumption \\ $=$ Exchange Rate IDR/USD \\ $=$ Employment opportunities \\ = Primary money \\ $=$ Money Supply \\ $=$ Gross Domestic Product \\ $=$ Tax Revenue \\ $=$ Multiplication of the Exchange rate and \\ International Price Index \\ $=$ Difference of BI interest rate with LIBOR \\ $=$ Subsidy \\ $=$ Disposable Income \\ = National Domestic Income
}

Stages of processing data in the study include the unit root test and cointegration test. Method for model estimation for short-term period use Error Correction Model-Engle Granger (ECM-EG) and the long-term period estimation using Two Stage Least Square (2 STLS).

The equations used in this study are the simultaneous equations, so that the model stability test is done indirectly. If simultaneous equations are stable, then the system will converge to a solution of dynamic [18]. If simultaneous equations are not stable, then the system will not converge so that there is no dynamic solution. The method used to test the stability of the model in this study is the CUSUM test by Brown, Durbin and Evans [22]. The model stability test is a procedure to determine whether the parameters of the model are stable in the period of the study. CUSUM test is based on the cumulative value of the recursive residuals. The cumulative value of these residuals with the band and then we plot a $5 \%$ critical lines. If the value of the cumulative recursive residuals is in the band, indicates the stability of the estimated parameters in the study period [23].

\section{RESUlt AND Discussion}

\section{A. Unit Root Test and Cointegration Test}

Stationarity test of data is done using the unit root test Augmented Dickey Fuller (ADF). Stationarity test data that has been performed on 23 observation data with the test equation includes a constant (intercept) at the 5\% critical value of the test is obtained that 6 variables are stationary at zero level are PDBE (Gross Domestic Products), YD(Disposable Income), BIRATE (Bank of Indonesia Interest Rates), RINTR (Difference of BI interest rate with LIBOR), HREKS(the relative price of the export commodity), and HRIMP (The Relative Price of the Import Commodity). Two variables are stationary on the degree of two (second difference) is $\mathrm{Y}_{\mathrm{DOM}}$ and LK, and the remaining variables are stationary at level one (first difference).

Cointegration test were conducted to determine the relationship between variables in the model were estimated. If the each of the variables has cointegration, means there are long-term balance between variables. Johansen cointegration test is used to determine the cointegration in the number of variables. From the all equation which has conduct cointegration test shows that all the variables in each model occurs cointegration between the variables. The results of data processing by using E-views 6 software are shown in Table I below.

\begin{tabular}{lcc}
\multicolumn{3}{c}{ TABLE I: COINTEGRATION TEST RESULT } \\
\hline \hline \multicolumn{1}{c}{ Equation } & Trace statistic & 0.05 \\
& & Critical Value \\
\hline Consumption & 34.004 & 29.797 \\
Investment & 59.943 & 29.797 \\
Government Expenditure & 72.528 & 29.797 \\
Export & 56.416 & 42.915 \\
Import & 79.252 & 47.858 \\
Money Supply & 73.669 & 47.856 \\
Exchange Rate & 58.971 & 47.856 \\
Price and PPP & 76.964 & 47.856 \\
Net Foreign Account & 39.113 & 29.797 \\
National Production & 30.807 & 29.797 \\
Employment & 37.112 & 29.797 \\
\hline \hline
\end{tabular}

\section{B. Estimated Model for Short Term and Long Term Period}

Estimation results of short-term and long-term for each block are as follows:

The results of data processing show that the error correction coefficient $\mathrm{EC}_{\mathrm{t}}$ is statistically significant imbalances, ECM specification means that the model used in this study is valid, namely short-term model of private consumption in balance. Differences in value of actual consumption with the value of the balance about 0.243 will be adjusted in just 9 months. In the short term, the variable of interest rates has negative and no significant effect on consumption. The long-term estimate results show that there is a significant variable, based on the F-stat is 1602.067 which mean that interest rates variable and disposable income can explain the predictive value of changes in private consumption.

Results of regression and analysis of short-term model for ECM-EG investment equation based on the t-test is -1.882 , a balance in the short term investment in the model. The difference between the actual investment values with an investment balance about 0.09 , adjustment will occur in 
about 10 quarter or 30 monthly. In the short term, the investment model with interest rates variable and capital flows have coefficients with corresponding directions in theory, but the two variables are not significant

Short-term analysis on the model of government expenditure, obtain the results of the t-test of -5.774 . Difference in the actual value of government expenditure to the balance value of 0.598 , the adjustment of the model will occur in less than 1 quarter or approximately 2 months. Model of fiscal policy through government expenditure in the short term only $30.1 \%$ explained by the tax revenue variable and national income variable. The long-term estimate results show that the model can explain of $87.5 \%$. The proportions of change with increasing the tax revenue by $10 \%$, will affect the government's policy of fiscal expenditure increased by $1.26 \%$ ceteris paribus, and the rising of national income in the economy will also increase government expenditure by $8.9 \%$ ceteris paribus.

Difference in the actual value of exports to the value of the balance is equal to $0.129 \%$ so the adjustment will take approximately 20 months. Model is able to explain $55.6 \%$ of the variable through the foreign relative price index for domestic and variable volume of world import demand. In the long run, the simultaneous equations of national exports can be explained by $96.8 \%$ through two variables: the relative price of commodities abroad against domestic prices and world import demand. Any increase in relative commodity prices abroad relative to domestic prices by $10 \%$ would significantly affect the value of national exports rise by $6.29 \%$ ceteris paribus, while world import demand increases by $10 \%$ will significantly increase the value of national exports of $2.07 \%$ ceteris paribus.

The results of the estimated short-term import equation with ECM indicate there is a difference actual value of imports with a value of 0.335 for the balance to be adjusted in nearly 6 months. This model also explains that there is a significant variable that all independent variables can explain $70.9 \%$. In the long term, the model can explain the effect of changes in the independent variable of $97.8 \%$. In the short-term and long-term wholesale export most influential and significant than the other two independent variables. This indicates a close relationship between exports and imports of Indonesia during the study period.

Demand and supply of money in the financial markets interaction in Indonesia is assumed that the demand for money is equal to the supply of money. Money supply equation is affected by the demand for real money, the interest rate and national income. Short-term estimation results indicate that the differences in the actual value with the value of the balance of 0114 , so it will be an adjustment in the period of 23 months. In this model there is one significant independent variable, and the model can explain $47.1 \%$. In the long term, the estimation results indicate that the independent variables in the model show the percentage of a much larger effect, which is able to explain at $99.6 \%$. Supply of money in the Indonesian economy affected by the real money demand, it is more elastic than the national income and interest rates. This shows the strong influence of the transaction motive in money supply in Indonesia.

Exchange rate equation based on the estimation results in the short term with error correction $\left(\mathrm{EC}_{\mathrm{t}}\right)$, obtain a valid model. There is a difference with the actual value of the balance value of 0.387 to be adjusted within 1.5 quarters or almost 5 months. Exchange rate model is able to explain $39.2 \%$ change in the exchange rate of the value predicted for the change of independent variables, which is the ratio of the domestic price index, international price index, interest rates and capital flows. Estimation results in the long term with simultaneous equation shows that the model is valid, i.e. all independent variables had a significant relationship to the variable rate. All independent variables in the model is able to explain the exchange rate of $94.1 \%$.

Capital flows is the value of a variable net wealth abroad (net foreign assets). Bank of Indonesia has to anticipate the entry of capital inflow in the form of foreign direct investment (FDI), the capital and financial account. Foreign net wealth equation is affected by the difference in interest rates in the country (domestic) on the level of international interest and exchange rates.

The equation of national production in the short term obtained valid model, so there is a balance in the short term. Difference in the actual value of national production towards its equilibrium value of 0.184 will be an adjustment in the period of 4 quarterly or about 13 months. In the short run, the aggregate supply curve is horizontal, because wages and prices are sticky at predetermined levels. Therefore, shifts in aggregate demand affect output and employment. When the number of workers increased by $10 \%$ would affect national production increased by $30.19 \%$ ceteris paribus. National production models obtained (according to the equation in the previous section) are as follows:

$$
\begin{array}{ccc}
\operatorname{LOG}(Y)_{t}=-8.296+0.206 \times \operatorname{LOG}(I)_{t}+3.019 \times \operatorname{LOG}(L)_{t} \\
t \text {-stat } \quad-19.372 \quad 7.546 & 24.879 \\
R^{2}=0.990 \quad \text { F-stat }=2816.69 \quad D W=0.590
\end{array}
$$

The employment opportunities equation estimation in the short term, through the models of the second difference data, did not get the valid models. The independent variables consisting of national production (GDP) and the price level is only able to explain $12 \%$, while $88 \%$ are influenced by other factors. Difference in the actual value of the equilibrium value is equal to 0139, adjustments will occur within 18 months. In the long run estimation results indicate that the independent variables can explain $97.9 \%$ of national output and the price level is believed to be able to predict the level of employment.

Stability test results for individually equation shows that the private investment equation, money supply equation and private consumption equation tend to be unsatisfactory or unstable according to criterion of CUSUM test. This condition can be explained that instability behavior of the independent variable, primarily due to shocks caused by changes in economic regimes [18]. Stability test result for private consumption equation in short term period and long term period can be seen in Fig. 1. The result stability test for investment equation can be seen in Fig. 2 and Fig. 4. The result of stability test for money supply equation in long term period can be seen in Fig. 3. The fourth picture shows the instability parameter in the equation, namely the equation of private consumption (for long term), investment equation (short term and long term) and the money supply equation 
(long-term), because all the line on the fourth image is outside the critical line of $5 \%$.

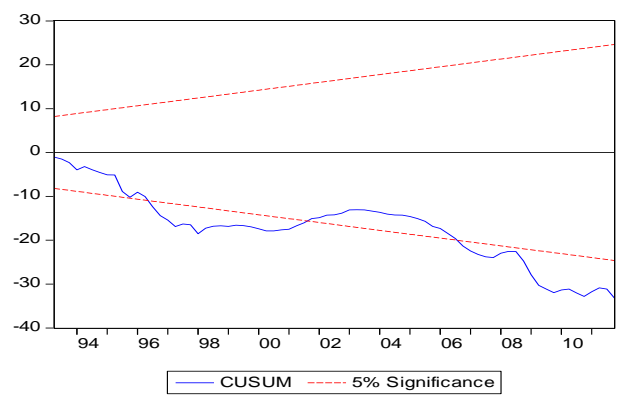

Fig. 1. Stability test result for private consumption (long term period)

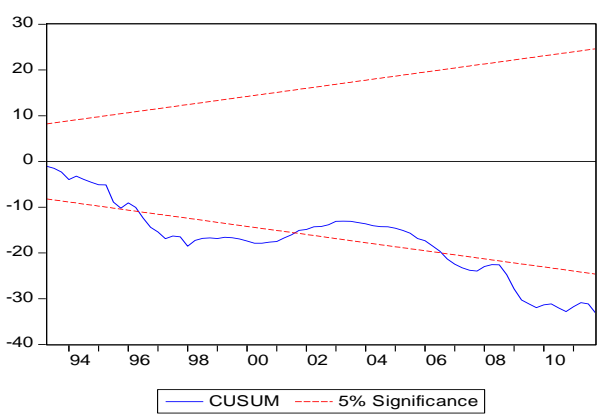

Fig. 2. Stability test result for investment equation (long term period)

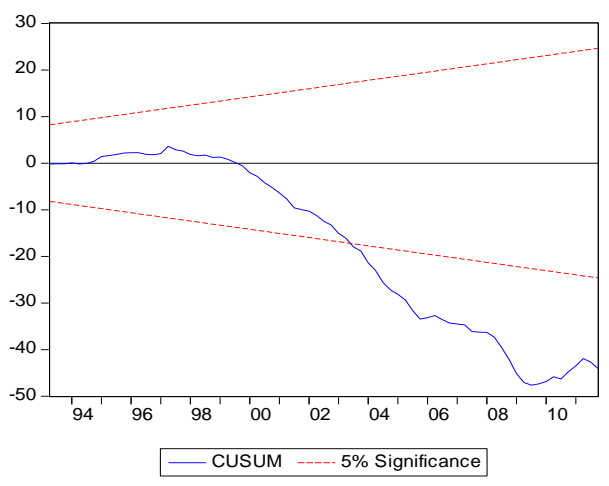

Fig. 3. Stability test result for money supply equation (long term period)

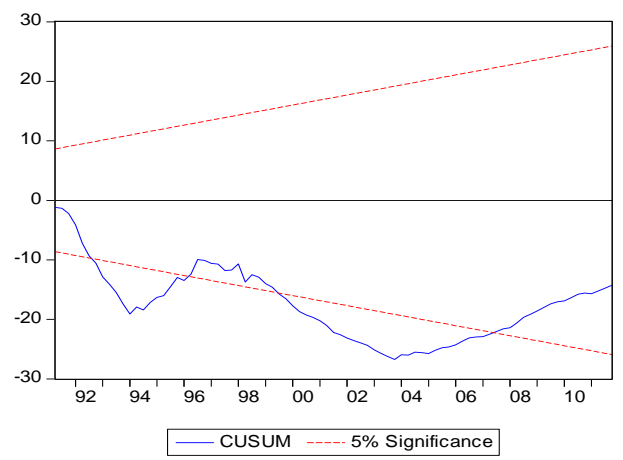

Fig. 4. Stability test result for investment equation (short term period)

\section{Discussion}

Indonesia's economic performance was colored by the dynamics of the global economy. The improving global economic growth boosted the volume of international trade as well as trigger a rise in commodity prices have an impact on the high export growth in Indonesia. Exports became the largest contributor to economic growth in Indonesia. High performance is increased to maintain the current account surplus, despite an increase in both sided, the high import side and the transfer profit or payment. Indonesian economy since the 1990s and before the 1997 financial crisis showed higher growth acceleration. Such as in 1994, 1995, economic growth was driven by strong domestic demand, in line with the high growth in investment and private consumption. Indonesia's economy in 2000 showed that the recovery process with a steady source of growth more balanced. Amid the uncertainty over the global economic recovery, the Indonesian economy grew stronger. GDP grew Indonesia increased from $6.2 \%$ in 2010 to $6.5 \%$ in 2011 as shown on Fig. 5 below.

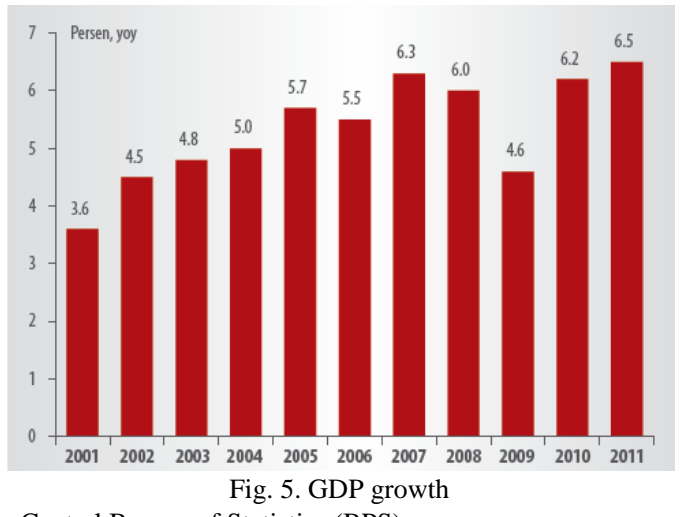

Source: Central Bureau of Statistics (BPS)

Structural changes in the Indonesia economy affect the application of Indonesian fiscal policy, monetary and GDP. Economic policy focuses on the management of macro-economic stability, fiscal policy will interact with monetary policy to control the macroeconomic balance [24]. Fundamental problem in the Indonesian economy is employment problems. Employment issues in Indonesia is influenced by several factors, which determine is foreign capital, investment climate protection, global markets and the behavior of the bureaucracy and the 'pressure' wage increases. It can be said that manpower in Indonesia is still facing some imbalances both structural and sector.

The magnitude of the effect of capital inflows indicates the strong influence of the movement of foreign funds in influencing the exchange rate. Therefore, the changing expectations of the economic outlook Indonesia followed by changes in foreign capital inflows will greatly affect the movement of the exchange rate

\section{SUMMARY}

Interest rates variable have a positive impact on the strengthening of the exchange rate. If the domestic interest rate is higher than the foreign interest rate, under the assumption of perfect capital mobility would certainly encourage the entry of foreign capital into the country in the form of investment. This study supports the previous research by [20] that the exchange rate plays an important role in the Indonesian economy. Increased foreign investment also means an increase in demand for domestic currency in the foreign exchange market.

The result show that fiscal and monetary policy is an 
integral part of macroeconomic policy, it has target that must be achieved in both the short and long term. This result support [2] that the combination of fiscal and monetary expansion is very effective to boost economic growth. Emerging that the trade-off between price stability and increasing in the achievement of national production (GDP), especially in the short term. Expansionary of fiscal policy which may result in increase in the rate of inflation, otherwise the economy with high inflation rates also negatively affect the increase in GDP.

\section{REFERENCES}

[1] Solikin, "Analisis Kebijakan Moneter Dalam Model Makroekonometrik Struktural Jangka Panjang," Buletin Ekonomi Moneter dan Perbankan, pp. 191- 229, September 2005.

[2] Simorangkir, Iskandar, and J. Adamanti, "Peran Stimulus Fiskal dan Pelonggaran Moneter Pada Perekonomian Indonesia Selama Krisis Finansial Global: Dengan Pendekatan Financial Computable General Equilibrium," Buletin Ekonomi Moneter dan Perbankan, pp. $170-$ 192, Oktober 2010

[3] F. S. Mishkin, "The role of output stabilization in the conduct of monetary policy," Working Paper, no. 9291, NBER, 2002

[4] Christiano, Lawrence, M. Eichenbaum, and C. Evans, "Monetary policy shocks: what have me learned and to what end? In Woodford, Michael and John Taylor (Eds)," The Handbook of Macroeconomics vol. 1 North-Holland, Amsterdam, pp. 65-148, 1999

[5] M. S. Rafiq and S. K. Mallick, "The Effect of monetary policy on output in EMU3: A sign restriction approach," Journal of Macroeconomics, vol. 30, pp. 1756-1791, 2008

[6] B. S. Bernanke, J. Boivin, and P. Eliasz, "Measuring the effects of monetary policy: A Factor-Augumented Vector Autoregressive Approach," Quarterly Journal of Economics, vol. 2, pp. 387-422, 2005.

[7] M. Yunanto and H. Medyawati, "Studi Mengenai Pembatasan Arus Mobilitas Modal dan Nilai Tukar (Kurs): Kajian Literatur," in Proc. Seminar Ilmiah Nasional PESAT Gunadarma University, 2011 pp. E. 80-E85, $18^{\text {th }}-19^{\text {th }}$ October 2011

[8] Al. Arif, M. Maulana, and A. Tohari, "Peranan Kebijakan Moneter Dalam Menjaga Stabilitas Perekonomian Indonesia Sebagai Respon Terhadap Fluktuasi Perekonomian Dunia," Buletin Ekonomi Moneter dan Perbankan, pp. 145 - 177, October 2006

[9] H. Siregar and D. B. Ward, "Can Monetary Policy Shocks Stabilize Indonesian Macro-Economy Fluctuations?" presented at the 25th Annual Conference of the Federation of ASEAN Economis Associations in Singapore on 7 - 8 September 2000

[10] C. Freedman, M. Kumhof, D. Laxton, and J. Lee, "The Case for Global Fiscal Stimulus," IMF Staff Position Note 09/03 (Washington: International Monetary Fund), 2009

[11] O. Blancard and R. Perotti, "An Empirical Characterization of Dynamic Effects of Changes in Goverment Spending and Taxes on Output," Quartely Journal of Economics, vol. 117, pp. 139-168, 2002

[12] C. Romer and D. Romer, "The Macroeconomic Effects of Tax Changes: Estimates based on a New Measure of Fiscal Shocks," (Unpublished Manuscript: University of California at Berkeley), 2008

[13] R. Perotti, "Estimating the Effects of Fiscal Policy in OECD Countries," CEPR Discussion Paper, no. 4842 (London: Centre for Economic Policy Research), 2005

[14] L. Christiansen, "Fiscal Multipliers-A Review of the Literature," Appendix II on IMF Staff Position Note 08/01, Fiscal Policy for the Crisis" (Washington: International Monetary Fund), 2008.
[15] F. Giavazzi and M. Pagano, "Can Severe Fiscal contractions be Expansionary? Tales of Two Small European Countries," NBER Macroeconomics Annual, 1990 (Cambridge, Massachusetts, National Bureau on Economic Research), pp. 75-122, 1990

[16] R. Hemming, M. Kell, and S. Mahfouz, "The Effectiveness of Fiscal Policy in Strimulating Economic Activity - A Review of the Literature," IMF Working Paper 02/208 (Washington: International Monetary Fund), 2002

[17] M. Firman, "Fiscal and Monetary Policy Interaction: Evidences and Implication for Inflation Targeting in Indonesia," Buletin Ekonomi Moneter dan Perbankan. pp. 359-386, September 2004.

[18] R. Maryatmo, "Dampak Moneter Kebijakan Defisit Anggaran Pemerintah dan Peranan Asa Nalar Dalam Simulasi Model Makro-Ekonomi Indonesia (1983:1-2002:4)," Buletin Ekonomi Moneter dan Perbankan, pp. 297-322, September 2004

[19] S. Iskandar, "Koordinasi Kebijakan Moneter Dan Fiskal Di Indonesia: Suatu Kajian Dengan Pendekatan Game Theory," Buletin Ekonomi Moneter dan Perbankan, pp. 5 - 30, January 2007

[20] Joseph and P. R. Charles et al. "Kondisi dan Respon Kebijakan Ekonomi Makro Selama Krisis Ekonomi Tahun 1997-98," Buletin Ekonomi Moneter dan Perbankan, vol. 2, no. 2, September 1999

[21] N. Yoshino, Presentation Materials at UREM, August 1998, Unpublished

[22] R. L. Brown, J. Durbin, J. M. Evans, "Techniques for testing the constancy of regression relationships over time," Journal of the Royal Statistical Society, vol. 37, pp. 149-163, 1975.

[23] W. Agus. Ekonometrika Teori dan Aplikasi untuk ekonomi dan bisnis, Ekonisia, Faculty of Economics UII, Yogyakarta, 2007.

[24] Y. Muhammad, "Dampak Kebijakan Fiskal dan Moneter Terhadap Produk Domestik Bruto (PDB): Indonesia Tahun 1990-2011," Dissertation, Gunadarma University, Indonesia, 2013

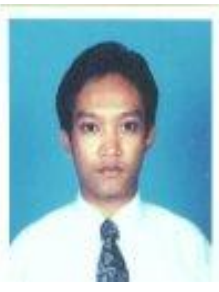

Muhammad Yunanto is a lecturer in Gunadarma University. Birth in Klaten, June 12, 1969. Undergraduate Program in Economics, Master Program in Management, and completed Doctoral Program majoring in Economics in Gunadarma University, Indonesia, in 2013. Lecturer in Gunadarma University since 1993, teaching subject in Macro Economics, Strategic Management, and Managerial Economics.

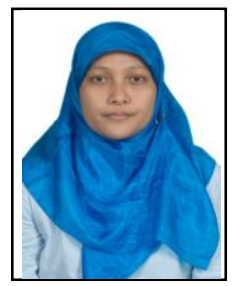

Henny Medyawati is a lecturer in Gunadarma University. Birth in Jakarta, May 18, 1970. Undergraduate Program in Computer Science, Master Program in Management, and completed the Doctoral Program in Economics at Gunadarma University, Depok, Indonesia, on March 5, 2010. Lecturer in Gunadarma University since 1993, teaching subject in Banking Information System, Electronic Banking, and Management.

She experience as an instructure in banking system application course, and attended in SAP course in Fundamental and Financial Module at Gunadarma University. As a lecturer, she also served in the head development laboratory at LEPMA in Gunadarma University (Management and Accounting Development Board). After attended the ICEBI 2011, she joint as member of IEDRC. 